\title{
George Gilbert
}

\section{RIGHTIST RITUAL, MEMORY AND IDENTITY COMMEMORATION IN LATE IMPERIAL RUSSIA}

This article explores how Russia's right-wing groups drew upon concepts of memory and identity commemoration to inform their ritual practices. Their creation of various memorials, celebrations and cults represented a synthesis between conservative values of Orthodoxy, autocracy and Russian nationality, and a populist nationalist appeal that came to define the ideology and practice of the Russian ultra-right in the final years of tsarism. The analysis includes three different case studies. First, it explores the creation of a leadership cult amongst the radical right, assessing how followers celebrated the memory of the leader of the Russian Monarchist Party, Vladimir Gringmut, after 1907. Second, it analyses the activity of one of the most militant groups on the Russian far right, the Union of Russian People, in Ukraine during 1905-07. Finally, it considers the activity of the Union of the Arkhangel Mikhail in Bessarabia and their staging of commemorative activities in celebration of the centenary of Bessarabia's incorporation into the Russian Empire, held in 1912. All of these examples demonstrate how an illiberal, populist monarchism was developing away from the Russian state and even in conflict with it.

The funeral of the Russian monarchist leader Vladimir Gringmut in October 1907 drew thousands of supporters from across the empire to central Moscow. The crowds formed processions, which hoisted aloft banners and flags, and sang songs as they wound through Red Square to the nearby Skorbiashchenskii monastery. This event was a powerful visual demonstration of monarchist values, providing a public forum for ideals to be shared between leaders and followers. Supporters of Gringmut subsequently presented this event as sacrosanct, detached from politics and calm; indeed, the demonstration, despite the agitated state of the large crowds, passed off peacefully. ${ }^{1}$ Followers described Gringmut as the leader of the monarchist movement and a spiritual figurehead for all of the Russian people to unite around. ${ }^{2}$ Rightist groups and their leaders used the power of social phenomena such as funerals, requiems and monuments celebrating the lives and deaths of Russian rightists to promote their own values, providing followers with opportunities to see, hear and even touch the values of popular monarchism. These emotive occasions, which included funerals such as Gringmut's, were used to inculcate certain cultural ideals in followers; however, they also proved to be contested events. 
The central subjects of study in this article - 'the right' or 'rightists' - refer to a distinctive set of interests: the right-wing groups that emerged after 1900 and especially during the revolution of 1905 . These are sometimes known in the historiography as the right-wing parties, monarchists or 'black hundreds. ${ }^{3}$ Two groups from this faction, the Russian Monarchist Party (RMP) and the Union of Russian People (URP), will be under special consideration, though examples of other major monarchist groups such as the Russian Assembly, the Union of Russian Men (URM) and the Union of Archangel Mikhail (UAM) will be drawn upon where appropriate. ${ }^{4}$ Rather than attempting to present a single sociological thesis on the power of ritual, this article will draw on a range of telling historical examples in order to illuminate how right-wing rituals were used for mobilisation purposes, with the aim of building support for such groups. Three separate studies (Vladimir Gringmut from 1907, URP funerals in Ukraine from 1905-07 and rightist involvement in the Bessarabia centennial celebrations of 1912) illustrate how rightist rituals in the early twentieth century were developing separately from the autocracy. Together they formed an alternate vision of how popular monarchism could be constructed, which led to the creation of an independent right-wing ritual subculture. This argument will be explored by examining right-wing violence, the use of anti-Semitism, nationalism in non-Russian areas of the empire, and the creation of both Russian and non-Russian identities.

Though rightists had appeared before 1905, events in the revolutionary era including military defeat to Japan in the war from 1904 to 1905 , the revolution of 1905, the promulgation of the October Manifesto and the convocation of a legislative elected parliament all functioned as catalysts for a wider process of right-wing group formation. Many groups on the right and the left attempted to harness popular support in Russia's semi-constitutional system. However, given that groups such as the URP and RMP reacted to the political developments of the era with dismay, it comes as no great surprise to discover that their associated ritual practices drew upon older symbolic forms, untainted by what they perceived as the corrupting effects of contemporary decline. This included frequent recourse to Orthodox iconography, as associated with the church service, liturgies and icon processions, prayers to 'the fatherland' (otechestvo), images of the resurrection of Christ, banners with traditional Slavonic lettering and images of saints such as Georgii Pobedonosets (significantly, the surname means the bringer of victory) who appeared on the URP badge. ${ }^{5}$ Such themes were derived from the ideals of 'official nationality' (Orthodoxy, autocracy and nationality) promoted by the Romanov dynasty itself, ${ }^{6}$ and the techniques used on the right mirrored those of the monarchy, which also celebrated past military victories, developed patriotic music and held national celebrations and festivals. ${ }^{7}$ Like other social and political groups, rightists used rituals to attempt to secure public support. Reflecting wider trends in contemporary Europe, rightists desired that these demonstrations in the theatre of public life would have a degree of popular resonance by appealing to the masses. ${ }^{8}$

In assessing the right's use of rituals and symbols, several wider conclusions can be drawn. First, the public demonstration of these rituals demonstrates the alternative view of the monarchy promoted by autonomous right-wing movements. Whilst rightists adopted the regime's ethos, most notably by sharing the banner of official nationality, they added new elements to those in existence, creating a synthesis between official and popular monarchism. Furthermore, there were ideological distinctions developing between the two tendencies. A shared agreement on the importance of Russian 
nationality did not prohibit different interpretations of that same principle. ${ }^{9}$ The constraints - or lack thereof - placed upon the right by the tsarist authorities can shed light on the relationship between Russia's rulers and the forces of right-wing radicalism. Second, analysing rituals and symbols can help us to understand the popular impact of the right by looking at how they demonstrated their consecrated system of values in public. Linked to this was the success of the right's attempts to woo the masses. Whilst rightists may have claimed a degree of popular support, how successful were they in actually achieving this aim? Third, the right's uses of rituals and symbols can tell us where the right fitted into the wider social, cultural and political context of late imperial Russia, by showing how they perceived a rapidly changing socio-cultural environment, and also how other national, political and religious groups reacted to them.

\section{Right-wing tactics and the use of rituals}

The adoption of 'the people' as part of a national myth had been previously pursued by the imperial regime in the idea of the 'good tsar.' ${ }^{, 0}$ Though right-wing groups were also committed to the ideology of 'official nationality', constructing rituals was in reality a dynamic process that led to the creation of scenarios that were in effect a departure from those long espoused by the regime. There are several ways in which to view this contrast between theory and practice, though one useful distinction is that between public and private rituals. In private, rightists commonly feted reactionary 'tough' heroes such as Alexander III, but in public, rightists chose subjects that they believed had a greater popular resonance. One example was the presentation of a bust in honour of Alexander II, the 'tsar liberator', in September 1912 in Vladimir province in front of monarchist peasants. Attended by representatives from the Vorshinskii branch of the URP, the right attempted to show that tsarism still had popular support whilst attempting to establish its own credentials as a movement of the people. In choosing the 'tsar liberator', monarchists desired to reach out to peasants by showing them how they too venerated the tsar who had emancipated the peasants from serfdom in 1861. After local peasants had sung pro-autocracy hymns, V. M. Koriakin, a URP activist, gave a speech about 'the important events from the life of the tsar-martyr, since the peasants asked why he submitted to the feelings of his loyal subjects. ${ }^{11}$ The presentation of the tsar as a martyr dying for his subjects was a theme embedded deep in the Orthodox tradition. Conservatives had reacted strongly to this image long before the right emerged in our period. For instance, the Slavophile publicist and thinker Ivan Aksakov wrote the following tribute to Alexander II after his assassination in 1881:

God raised the humble one to a height above any earthly height ... Whose hand there was ready to go into battle for the defence of his throne ... a whole ocean of people, was worthy to die truly martyred. His image stands before us now in the radiant glory of a passion-sufferer. ${ }^{12}$

The powerful image of martyrdom was one example of how ritual demonstrations, developed on the right, attempted to arouse the emotions and feelings of the people observing them, though with the important caveat that these applied only to ethnic, 
Orthodox Russians. ${ }^{13}$ Another instance was in the bicentennial anniversary of the battle of Poltava, held in the spring of 1909. The celebrations were portrayed by rightists such as Father Ioann Vostorgov as mass events involving the people (narod), and in so doing rightists provided a vision of unity between elites and masses. Whilst the Petrine legacy was not a conservative one, the great military victory over Sweden in 1709 allowed even ardent rightists such as Vostorgov to interpret Peter's legacy positively, even though it had often been disparaged for its 'Westernism' in conservative circles. ${ }^{14}$ These examples show how rightists, in seeking a mass audience, could use ritual practices in pursuit of mass support.

Many of these rituals involved the theme of death, which provided potential common ground between rightists and their intended audience. The Russian right desired that rituals involving this preoccupation cross classes and provide unity between people, tsar and the monarchist movements. ${ }^{15}$ In using this theme the right had chosen an influential idea with clear social significance. For example, in Russia's peasant community, death rituals were used to create a meaningful way of dealing with high mortality rates. ${ }^{16}$ Given high rates of both illiteracy and mortality in many of Russia's peasant communities, it is obvious why rightists may have placed special attention on images and symbols surrounding death in order to win support, rather than written texts. If they are carefully constructed and given the correct thematic appeal for their intended audience, public rituals can successfully demonstrate a consecrated symbolic system, which functions as a 'cultural performance' imposing an order on apparently chaotic and arbitrary events. ${ }^{17}$ Modes of the performance may vary. For instance, religious symbols used in funerals and memorials can serve to visualise 'ancestor worship', signifying respect for generations past and ties to the wider community. ${ }^{18}$ These themes were directly linked with rightist activities, which emphasised ideas of community, tradition, observance and religion. Examples included 'union banners, peasant choirs, church services, requiems and other purely religious rites that usually occupied no less a place than patriotic manifestations and the sending of telegrams. ${ }^{19}$

The goal of such rituals was to legitimise the rightist social order. The creation of 'sacred space' in public is an important part of this process, an area where the sanctity of what is taking place in front of observers cannot be questioned and takes on a detached, mythic and timeless quality independent of the normal plane of human activity. ${ }^{20} \mathrm{~A}$ novel development of certain right-wing rituals was that, unlike in the scenarios of the autocracy, the role of the narod changed from an essentially abstract focus, shared with the tsars, to the explicit personification of rightist favourites and followers. Ideas of protecting the sanctity of the people can be seen in the construction of the 'Memorial Church of Russian Sorrows' in Khodynka, Moscow by the Ekaterinoslav branch of the URP between 1905 and 1909. This was dedicated to '2,000 victims of revolution', one of whom was Grand Duke Sergei Aleksandrovich, killed by revolutionaries in Moscow in 1905. The remaining were all normal people, 'true tsarist subjects', killed by subversive forces in the new 'years of troubles' (smutnye gody). ${ }^{21}$ These 'subversive forces' were often taken to mean Jews and other national minorities by rightist activists, and many of these foes were also drawn from the political class. A combination of positive and negative ideals comprised a series of images, which Russian rightists desired would have emotional resonance for followers. Rightists used a mass-circulation press, public demonstrations, deployment of orators and activists, and the construction of memorials as techniques in aid of disseminating a message that they were groups on 
the side of the Russian people. ${ }^{22}$ Together they represented a move towards populist nationalist ideology from the autonomous right, with the attendant rituals performing the function of publicly legitimising such beliefs. All of these practices took place in the public realm shared with the state, but developed apart from it. Though rightists largely adhered to the same principles as the regime, they created an alternate vision of monarchy and empire in the late imperial period in response to processes of social and political change.

\section{Vladimir Andreevich Gringmut: a vozhd' of the movement}

The funeral and deification of Vladimir Gringmut by his followers was one instance of the right-wing parties celebrating their own heroes of the movement. Though this was a peaceful event, followers criticised the realities of the Russian present as created by the regime and, in doing so, highlighted the reactionary nature of Russian rightist forces. ${ }^{23}$ Gringmut was the editor of the monarchist newspaper Moskovskie vedomosti (Moscow News) from 1896, and creator and leader of the RMP from 24 April 1905 until his death on 28 September $1907 .^{24}$ Large crowds gathering on 1 October to mark Gringmut's passing showed that an independent right had emerged that could mobilise a significant number of followers. In several respects the symbolism of the funeral, which drew on Orthodox religiosity and the power of Russian autocracy, mirrored the ideology of the regime. On the day of the funeral, a crowd of several thousand followers, led by the monk and orator Father Ioann Vostorgov, a close confidant of Gringmut and himself a leader of the RMP, gathered at Red Square to chant slogans and sing Orthodox hymns. Many of these musical renditions, such as 'God is with us' (bog s nami) and verses from Mikhail Glinka's 1836 opera 'A Life for the Tsar' (Zhizn' za tsaria) were typical of monarchist ritual. The procession formed at his funeral and wound its way from In Red Square, where several thousand followers and leaders of the movement had gathered, along Malaia-Dmitrovka and Dolgorovka streets to Skorbiashchenskii monastery. The funeral was a powerful visual demonstration of Orthodox religiosity, with the icons and flags of the RMP depicting various saints, the Virgin Mary and, of course, Gringmut himself. Supporters sang 'God save us!' and carried Orthodox crosses along the procession route. The interment of Gringmut occurred in the monastery that evening. Reportage from the event declared that 'the meaning of this will be fixed in popular memory', ${ }^{25}$ and emphasised the peaceful nature of the crowds. ${ }^{26}$

Monarchist followers described Gringmut's funeral, not without some justification, as a mass event that had attracted a broad cross-section of society. ${ }^{27}$ One sympathetic source estimated that over 30,000 people were present. ${ }^{28}$ This estimate seems high, though an important piece of surviving evidence is a series of photographs from the event, which shows crowds of at least several thousand (Figures 1 and 2). The crowd attending the event appeared to be socially mixed. Smartly attired men, some in uniform, peasant women in headscarves, as well as the drably dressed and not clearly identifiable were all present amongst the throng of supporters carrying banners and flags. Among those present were leaders of dozens of provincial branches of the RMP, various delegates representing a number of other monarchist groups from across the empire, the governor-general of Moscow, V. F. Dzhunkovskii, and Metropolitan Vladimir of Moscow and Kolomenskoe. The social base of the demonstration was 


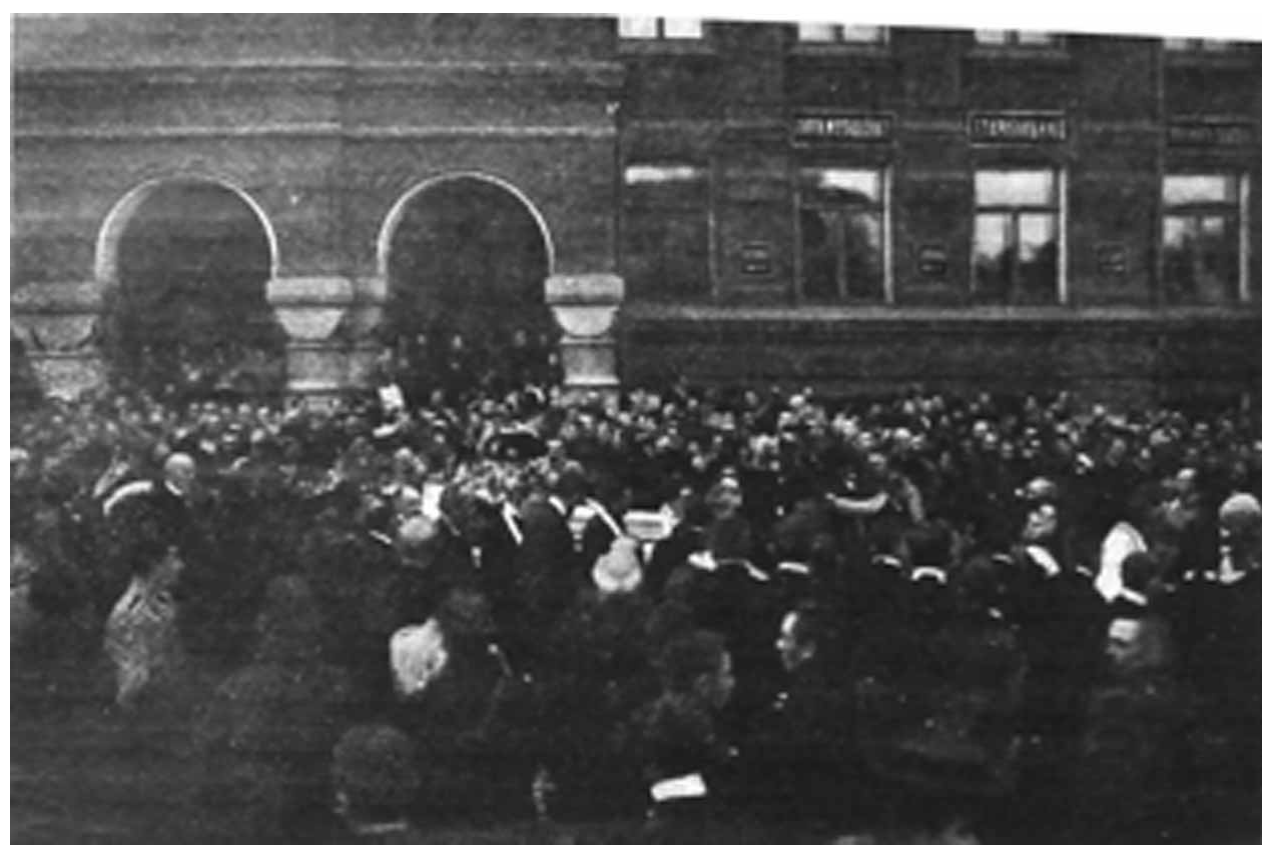

FIGURE 1 Crowds in Moscow for Gringmut's funeral, 1 October 1907.

Source: Vladimir Andreevich Gringmut: ocherk ego zhizni i deiatel'nosti, Moscow: A. A. Levenson, 1913, p. 118. Courtesy of the Slavonic Library, National Library of Finland.

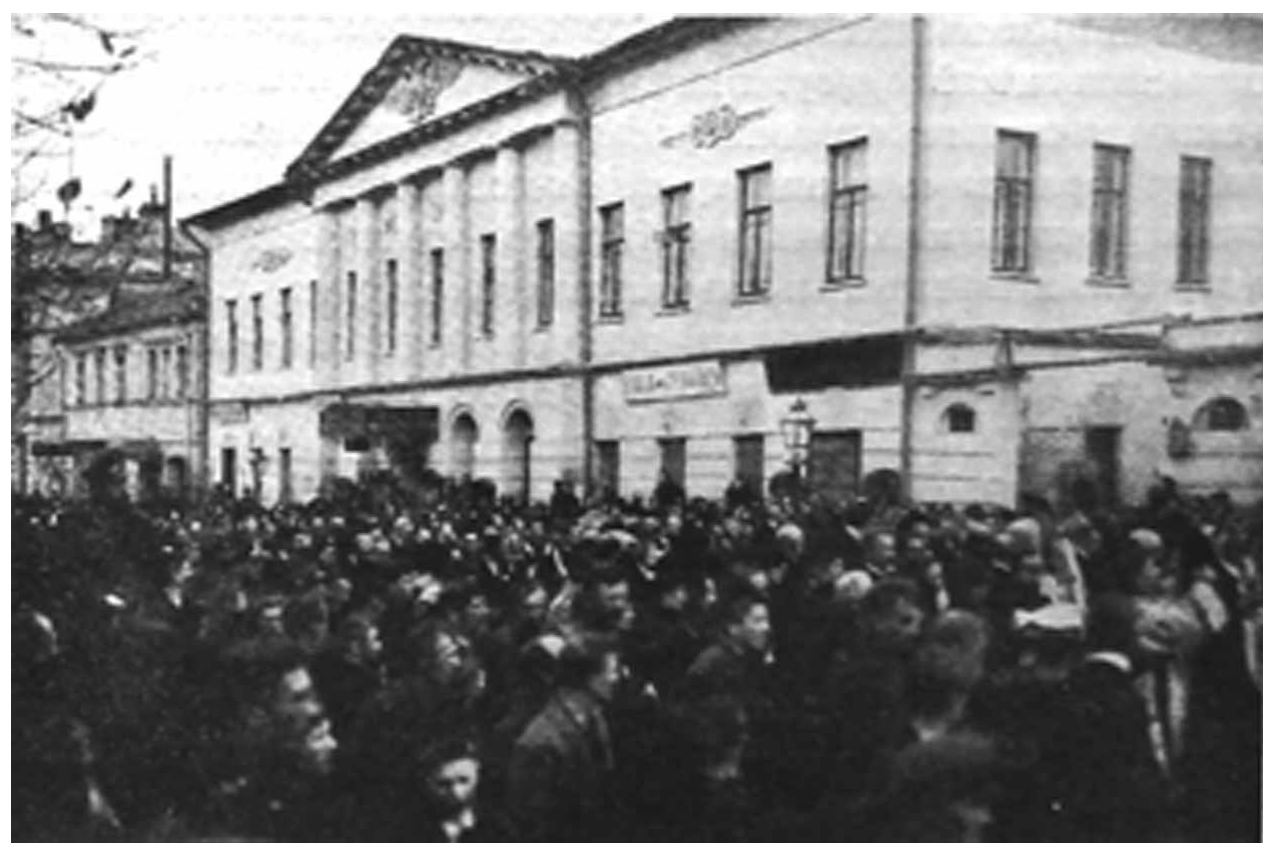

FIGURE 2 Gringmut's funeral procession, 1 October 1907.

Source: Vladimir Andreevich Gringmut: ocherk ego zhizni i deiatel'nosti, Moscow: A. A. Levenson, 1913, p. 119. Courtesy of the Slavonic Library, National Library of Finland. 
important, as rightists were generally keen to portray a degree of mass support. This event was portrayed as 'cross estate' (soslovie), aimed at both the elites and the masses, appealing for unity via the use of transcendent symbols of Orthodoxy and nationality, rather than political emblems. ${ }^{29}$

Much of the symbolism and iconography of the Gringmut cult was not novel. Several rightist groups, such as the Russian Assembly, frequently praised other conservative heroes like Alexander III using similar symbolism and language. ${ }^{30}$ However, a key difference was that the Gringmut cult had autonomous origins, and hence represented the development of an independent movement. Furthermore, there was a growing emphasis on Gringmut's role within the wider monarchist movement. The secular aspects of the Gringmut cult emphasised his personal values as a dynamic and independent leader of the movement. He was presented not only as an outstanding figure, but the focus of all convictions, and a warrior (bogatyr'). ${ }^{31}$ His supporters saw him as the 'outstanding individual talent' in the earliest years of the formation of a nationwide, mass-scale monarchist movement, and wished to demonstrate this through his cult. ${ }^{32}$ In this way Gringmut's 'leadership cult' demonstrated some commonality with those of fascist and totalitarian regimes later on; however, rightists typically stressed unity, nationality and religion in their own cults, and, of course, their own leaders' roles could not completely override that of the tsar. ${ }^{33}$ The cult's symbolism was a unique mixture, consisting of Russian Orthodox symbols long familiar to followers, and also iconography that presented the individual as a 'heroic' personality. ${ }^{34}$

Once the funeral was over, the focus turned to the legacy of Gringmut. Despite protestations from Gringmut's supporters that his legacy was not political, the role of politics warrants consideration as part of the scenario. Whilst the development of a Gringmut cult was not in obvious conflict with the regime, followers criticised widespread decline in contemporary Russia, and saw that Gringmut had a 'mission' to restore the nation. According to Boris Nazarevskii, chair of the Russian Monarchist Society writing in the newspaper Staraia Moskva (Old Moscow), this was to re-energise the Russian people, in spirit and religion, as well as to create a party machine. ${ }^{35}$ At a requiem (panikhida) for Gringmut, held at the Skorbiashchenskii monastery on 30 March 1908, a crowd of bishops, archimandrites, priests and members of the RMP sang monarchist hymns, including arias from Glinka's opera, and listened to a speech given by URP member and right-wing commentator A. S. Shmakov, which opined on threats to Russia in the political era. In contrast to Nazarevskii's tribute, Shmakov's speech was more aggressive: essentially, it was a lengthy criticism of the recently established State Duma. Shmakov argued that the Duma was only interested in 'passing Jewish laws', and stood as the foremost bridge between the selfrealisation of the Russian people and the spiritual degeneration of the nation. This echoed the ideas of Gringmut, who had been a virulent anti-Semite and opponent of the Duma system. ${ }^{36}$ As Gringmut had declared in an editorial in June 1906, the leadership of the monarchist movement would carry out the 'will of the tsar' and would co-operate with the Duma only grudgingly. Gringmut's legacy attracted diatribes against politics, and demonstrates the negative core of the cult, as his supporters widely decried the situation in contemporary Russia. ${ }^{37}$

Gringmut was a headmaster at the Tsarevich Nikolai Lyceum in Moscow between 1870 and 1895. Playing on this previous role, the theme of Gringmut as teacher was prominent in a report from 30 September 1908. RMP member I. A. Kolesnikov had arrived in Moscow to open a school established in Gringmut's name, aiming to carry 
on his brand of teachings. This reveals the priority that youth groups were accorded by monarchists. Followers such as Kolesnikov claimed that Gringmut was more than a political leader - he was also described as a spiritual teacher of Russia's youth. Continuing the theme from the funeral itself of appealing to the masses as well as the elites, the school was free and ostensibly aimed at poor students. One quote described him as 'the dear leader and unifier of the Russian people, father-warrior (bogatyr') Gringmut. ${ }^{38}$ In a similar tribute from July 1909, B. V. Nazarevskii reported to delegates at a conference in Moscow that a church school in Siberia had opened, primarily aimed at peasants, which gave special instruction on Gringmut's life and teaching. Selected spiritual texts, Gringmut's own works and RMP pamphlets would be distributed amongst the students, as in the case of the school in Moscow. ${ }^{39}$

Monarchist propaganda presented Gringmut's most outstanding personal achievement as organisation and leadership of the wider monarchist movement, and relegated his role as a thinker to secondary status. Here, Gringmut's role as a political leader was emphasised. In one tribute from a rightist journalist, Nikolai Chernikov (a member of the Russian Assembly), he was seen as an outstanding publicist in light of his editorial duties and, furthermore, an inspirational leader of patriotic activities. Gringmut was described as a fighter for 'Russian rights' who had waged 'war with the enemies of Russian unity. ${ }^{40}$ V. P. Meshcherskii, an influential member of the tsarist court camarilla, a confidant of Nicholas II, and the editor of the reactionary newspaper Grazhdanin (Citizen), held that Gringmut's role, unlike his editorial predecessor at Moskovskie vedomosti Mikhail N. Katkov, had not been primarily as a thinker, but rather as a man of action. He was declared to be a vozhd', not merely a leader, but one with special strength and vision. Gringmut represented a man of unbending personal will in a time of weakness. ${ }^{41}$ Supporters praised the exponential growth of the monarchist movement, from a handful of members in Moscow to several hundred branches throughout the empire, which was said to be a result of his guidance. ${ }^{42}$

A series of book publications between 1910 and 1913 added to the tributes dedicated to his memory. Gringmut's collected works, consisting of essays, columns from Moskovskie vedomosti and letters from across the Russian Empire addressed to him, were re-published in collected form. ${ }^{43}$ Members of a number of monarchist organisations including the RMP had written to major monarchist newspapers and journals, such as Russkoe znamia (Russian Banner), Grazhdanin, Vestnik Russkogo sobraniia (Messenger of the Russian Assembly), as well as the paper previously edited by Gringmut, Moskovskie vedomosti, making some extravagant claims that he was the monarchist who had given the movement its impetus. Some even claimed he had represented a spiritual leader of the Russian nation. ${ }^{44}$

The Gringmut cult, far from criticising tsarism, even appeared to defend it. Indeed, the official badge of the RMP was dedicated to Nicholas II, bearing a quote attributed to him, 'may my autocracy stay as of old.' However, a significant result of the cult was the construction of an alternative vision of monarchism, based not only on the same principles of the regime but also on a profoundly pessimistic mood regarding the Russian present. Rejection of political developments, such as the creation of the State Duma, demonstrated a schism between official and populist monarchism, with many devotees of the latter tendency resolutely opposed to such changes. ${ }^{45}$ Another wider point is how much of the energy created by Gringmut's deification had a negative focus, and was directed against the enemies of the Russian state, rather than in pursuit of creating a 
positive ideal. Consequently, many of his followers did not view the status quo in Russia with optimism. Gringmut, along with right-wing leaders G. V. Butmi, A. I. Dubrovin and the commentator K. N. Paskhalov, was a monarchist who did not wish for any sort of representational system in Russia. ${ }^{46}$ He instead wanted direct and 'indivisible' links between leaders, organisations and people, and hence to dispense with any parliamentary system. ${ }^{47}$ Above all, he saw the RMP as an all-class movement, beyond mere political aims, and for ethnic Russians only. This theme was reflected throughout the monarchist press, and at requiems and assemblies held for Gringmut, all of which praised his memory. According to one recent analyst, 'he declared that the black hundred movement had a higher and greater aim: the desire of a national and religious revival of the Russian people. 48

Unlike Alexander II, Gringmut had died of natural causes, so his own chance of martyrdom was denied. Instead, he was given a role as a steadfast defender of 'Russian' values. Supporters such as Ioann Vostorgov depicted him as a man of the people who had united the popular mood. In a speech given by Vostorgov at the funeral, he stressed that at the event:

There were no crowds, no idlers and senseless gatherings, there was, in place of this, a popular mood united in profound veneration and prayer ... between us we have seen that the death of Vladimir Andreevich was felt by thousands of people, many circling his coffin, as the death was dear to native men, who have rarely shed so many pure and just tears. ${ }^{49}$

The targeting of enemies, a common feature among the Russian right, was also present in the tributes. This included recourse to anti-Semitism, a frequent feature of the far right. Vostorgov referred to the 'despicable words of one Jew' in the press, who had reportedly commented on the surprisingly low turnout at the funeral, something Vostorgov denied in his speech. ${ }^{50}$

The final piece in the development of the cult was a large monument that was unveiled in the cemetery of the Skorbiashchenskii monastery in Moscow on 25 April 1910 (Figure 3). Supporters claimed this part of the cult was operating on a purely religious basis, and reportage of the event presented a series of Orthodox rituals. Unlike at Gringmut's funeral, the party organisation of the RMP did not figure as a prominent presence at the unveiling. ${ }^{51}$ The monument was designed by the architect and artist (and himself a member of the right-wing movements) Viktor P. Vasnetsov, and was created by stonemason M. P. Ovchinnikov working in his shop. The body of the monument was constructed from only two pieces of granite. The top section of the edifice was made out of one massive granite block hewn by stonemason V. I. Orlov into the shape of an Orthodox cross. Another large piece of granite formed the base, and was inscribed with words dedicated to V. A. Gringmut: 'Orthodox Russian people: assemble, unite, pray.' The cross, which depicted icons of the Virgin Mary and the priest Ioann Bogoslov, was sculpted from solid bronze and raised separately from the granite fascia. It reportedly cost over 6,000 rubles to produce (Figure 4). ${ }^{52}$

The unveiling of the memorial was a major event for local monarchist groups, including members from the Mogilev branch of the URP. Grazhdanin reported how Vostorgov had given a speech to a delegation composed from a variety of major monarchist groups, with over 2,000 supporters present in all. ${ }^{53}$ Supporters had gathered to praise 


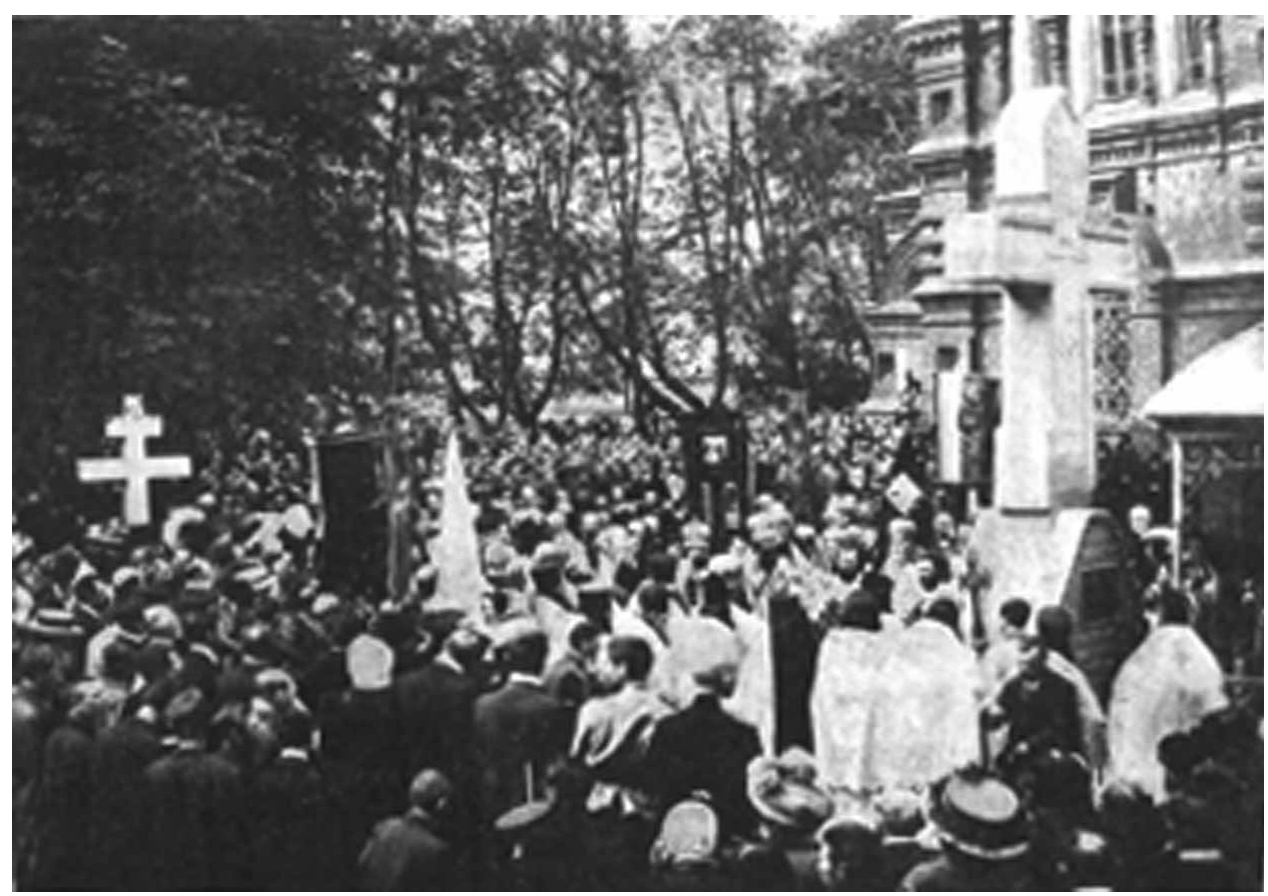

FIGURE 3 Gringmut's monument, Mogilev, 25 April 1910.

Source: Vladimir Andreevich Gringmut: ocherk ego zhizni i deiatel'nosti, Moscow: A. A. Levenson, 1913, p. 123. Courtesy of the Slavonic Library, National Library of Finland.

Gringmut's life and works, chanting 'Christ has risen! Christ has risen!' and 'God is with us.' Vostorgov declared at the unveiling of the monument, 'it is wonderful to hear that today we speak of you: look on the cross in silence, hear us cry for "true resurrection", hear us, and our words! ${ }^{54}$ Gringmut's values, including his supposed veneration of Russia and the Russian people, commitment to Orthodoxy, and nationalist ideology would live on, as supporters sought to 'resurrect' his ideas for a future age. ${ }^{55}$

However, not all monarchists were completely satisfied with the effusive praise that the cult provided. Whilst Mikhail Men'shikov recognised the personal qualities of 'will' and 'unwavering service' that Gringmut had given to the monarchist movement, he saw him primarily as a man betrayed by dark forces from the era. Men'shikov, a regular contributor to Aleksei Suvorin's influential St Petersburg-based daily newspaper Novoe vremia, considered that Gringmut had been ignored by Russia's rulers 'not because he did not have anything to teach them, but because the state idea was largely calibrated around a great many bureaucratic goals. And therefore Gringmut, like the majority of our publicists, wrote mainly for the bureaucracy.' Gringmut's death was interpreted by some on the right not as a sorrowful passing, but as a prelude to catastrophe, with Men'shikov claiming his life had demonstrated the weakness of the autonomous right. ${ }^{56}$ Men'shikov's diatribe reveals another aspect to the Gringmut cult. Though it appeared to have been peaceful, a wider mood of pessimism underscored a rejection of the realities of Russia's present. The spurning of political realities demonstrates a divide between the actions of the regime and the view of Russia's present as adopted by right-wing radicals. 


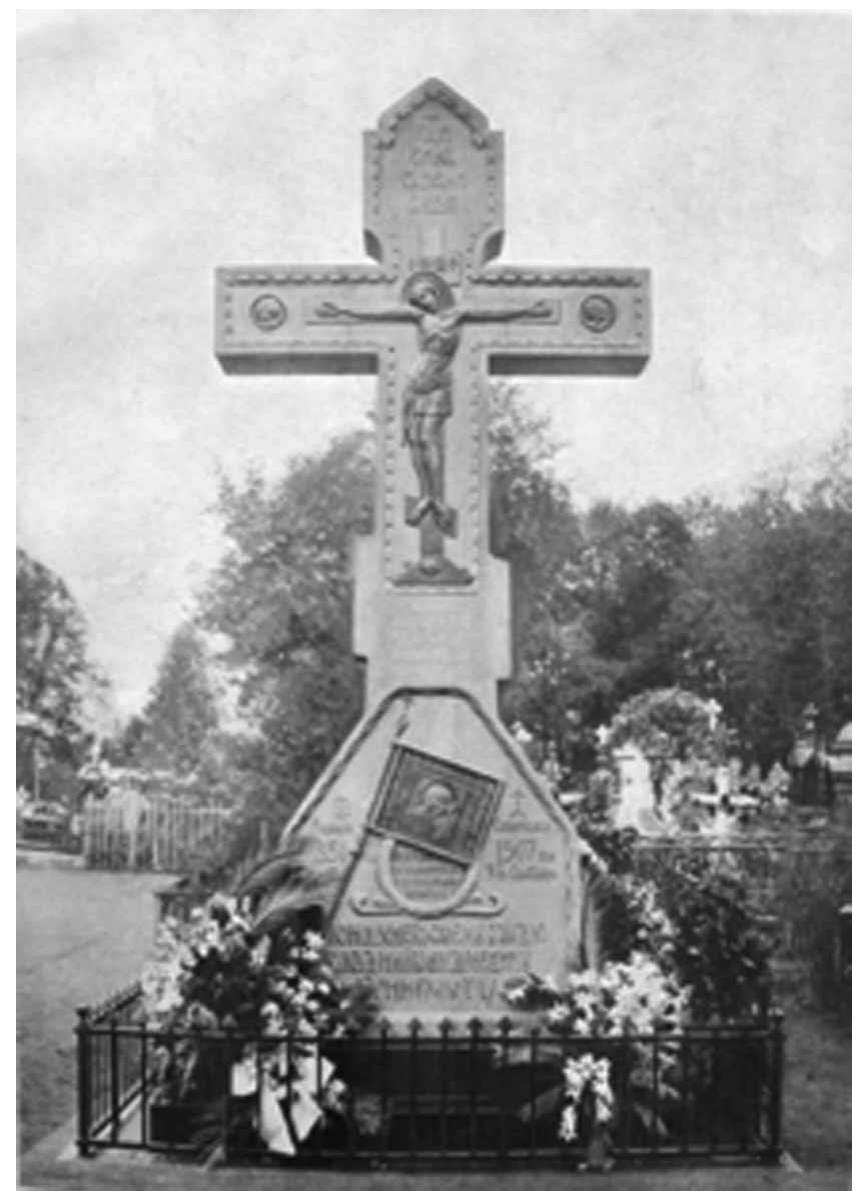

FIGURE 4 The Gringmut monument unveiled to crowds of monarchists, 25 April 1910.

Source: Vladimir Andreevich Gringmut: ocherk ego zhizni i deiatel'nosti, Moscow: A. A. Levenson, 1913, p. 121. Courtesy of the Slavonic Library, National Library of Finland.

\section{URP funerals in Ukraine, 1905-1907: populism, anti-Semitism and violence}

A particular stimulus for criticism of the Russian present was the presence of other social, political and national groups. On the imperial periphery, such conflict was more marked. This was particularly so in Ukraine, and especially in Odessa. Founded in 1794, the late nineteenth-century Odessa was the largest city in Ukraine and the fourth largest in the Russian Empire. It was an ethnically diverse city with many immigrant communities. Large numbers of people came in and out of the city's busy port area on a daily basis. One notable aspect of the city's demographics was its large Jewish population; demographic data from the final years of the empire show a sizeable community. In $1904,31.31$ per cent of Odessa's overall population of 511,000 was Jewish. ${ }^{57}$ The city was very prosperous, with many of its Jewish residents involved in the mercantile industries and financially successful, though this success was compromised by harsh restrictions on their civil liberties. However, tensions between Jewish and non-Jewish 
residents were bubbling underneath the relative wealth of the city, giving right-wing forces scope with which to use anti-Semitism as a tool to mobilise the masses. This aggression did not go unchallenged: the presence of active and well-organised Jewish self-defence forces in Odessa led to fierce recriminations, and violence emerged as a central element of right-wing activity there.

The membership of the far right was increasing immediately after the revolution of 1905. By 1907, the largest right-wing group, the URP, claimed around 1,000 branches across the Russian Empire. ${ }^{58}$ An estimate of the total membership of the organisation in the same year can be arrived at via examining police records in the Russian State Archive, which show between 300,000 and 400,000 members. ${ }^{59}$ A particularly active branch was in Odessa, established at the end of 1905, and led by Count Aleksei I. Konovnitsyn. He was particularly active recruiting workers from the dock areas, and presented his movement as one dedicated to 'the Russian people.' This was in stark contrast to the small-scale, elitist groups that had existed before 1905, such as the Russian Assembly. A widespread perception amongst supporters of the URP in Odessa was that the city was home to many revolutionary subversives and wealthy Jews, who oppressed poor Orthodox Russians. This became a key part of their propaganda. ${ }^{60}$ The far right portrayed a scenario in newspapers such as Russkoe znamia that being in a revolutionary group such as the Bund was typical of Odessa's Jews. ${ }^{61}$

Populism was a central element of the right's message during and after 1905. In Odessa and other parts of Ukraine, one strategy for popular mobilisation was holding public funerals for ex-members of the right-wing parties, many of who were workers who had joined the groups due to the recruitment efforts of the likes of Konovnitsyn. These public processions were initially presented by supporters of these groups and the right-wing press as detached and sacrosanct events that had little to do with everyday political activity. Like the Gringmut case, much of the symbolism of these events utilised the triad of 'Russian' values of Orthodoxy, autocracy and nationality that needed to be defended in a time of contemporary decline. One addition to the URP's message in Odessa was how it presented itself as a movement in defence of the masses, as well as of the three central values of the triad decreed by the Minister of Education, Sergei Uvarov, in 1831: Orthodoxy, autocracy and Russian nationality. The populist element in the right-wing message resulted in additional tensions, with funerals held for rightist workers providing an opportunity for far-right groups to portray themselves as defenders of 'the people. ${ }^{62}$ Russian rightists frequently presented themselves as under attack from external threats: the funerals and processions held for workers, and the demonstrations and chants accompanying them, were designed not to promote leaders or statesmen, but instead everyday 'true Russian' people. ${ }^{63}$ The image of the sanctity of the Russian worker was added to longstanding values of Orthodoxy and nationalism, creating a synthesis on the far right between populism and official nationality. Intriguingly, the presentation of images of the people had changed in the case of these funerals. The people were no longer merely passive receptors of the ideas of leaders as they had been in previous scenarios, but were the central focus of the right-wing mythos. Funerals for members of right-wing workers' groups acted as a trigger for waves of violence in defence of 'the masses' or common people against an 'enemy within' threatening to destroy Russia. ${ }^{64}$

The 'enemy within' was often depicted to be a Jewish one. Anti-Semitism was a central element of these popular events: crowds were invited by leaders to take out 
their anger on local Jewish populations. ${ }^{65}$ One funeral in Kherson province in Ukraine was held for the URP activist, and worker on the Odessa docks, Aleksandr Prokhorov on 28 February 1907. He had been killed in a clash between URP and revolutionary forces. His funeral was held in the nearby Kherson cemetery. Supervised by leaders of the local branch, A. A. Bankovskii and M. I. Ivanov, a police report noted how after the memorial service a crowd of several hundred URP activists were invited to 'unite for the fight with enemies', crying 'Russia is on the march! (Rus' idet) and 'hurray!' whilst promising to wage war, most of all against Odessa's Jews. Led by Bankovskii, the crowd carried banners, including the Russian national flag, filing down Petrovskii and Alekseevskii streets. A pogrom started and shops considered 'Jewish'looking had their windows smashed with bottles and stones and were set on fire. Scores of onlookers were injured in the chaos that engulfed the town centre. The violence subsided by the following day, but the sudden nature of these acts of violence had caused panic in the town centre and created an air of tension amongst residents. ${ }^{66}$

In other parts of Ukraine, members of the URP presented themselves as defenders of Russia against subversives, and in particular Jews. A report in the rightist paper Russkaia rech' (Russian Speech) dating from 12 May 1907 described a procession of at least 10,000 people in Ekaterinburg who had filed into the town centre via Preobrazhenskii Street. Religion was central to this construction of popular anti-Semitism: the procession was allegedly raised in protest at the disruption of an Orthodox funeral a few days earlier. URP activists amongst the demonstrators called for the 'defence' of a traditional, idealised Russia against revolutionary agitators, leftists and Jews, and declared that Orthodox Russians were 'naturally well-intentioned' in contrast to such enemies. The URP activists at this demonstration declared the disruption of the funeral to be an attack on Russian religion. One orator declared, 'what has it come to, when we are unable to give a quiet burial in the Christian tradition for a Russian man?' The houses of forces the right considered as their enemies, chiefly leftist students and Jews, were targeted in violent reprisals. ${ }^{67}$ The scale of this activity around ritual demonstrations shows that this popular anti-Semitism was making inroads into mobilising the local population.

A funeral held in Odessa for Polivanov, a member of a right-wing workers' organisation called the Russian Society for Trade and Industry (a small group related to the URP combat units in the town), attracted bands of URP supporters, who urged violence against Jews and leftists, often presented as indistinguishable in related propaganda. This was portrayed as revenge for Polivanov's death, supposedly at the hands of Jewish revolutionaries operating within the city. ${ }^{68}$ In another instance, right-wing activists exploited the shady circumstances of the murder of a city official in order to pose as the defenders of officialdom against attacks from left-wing radicals. This funeral provided rightists with what they perceived as an opportunity to pose as the defenders of law and order against what they described as waves of revolutionary violence and destruction. The Russian-Jewish newspaper Voskhod (Dawn) reported on the presence of A. F. Girs, assistant governor-general of Odessa, at the funeral for a murdered local official, Pogrebnii. Addressing crowds of supporters at the event, Girs placed the blame for Pogrebnii's murder on Jewish revolutionaries. He stated at the funeral, 'when we stand in place with the town governor we only ask: what for?' The solution was revenge attacks: 'brothers, take vengeance!' Rightists interpreted this as a call for violence and destruction; shops were looted and Jewish youths and students were attacked by 
bands of hooligans. The paper protested that it was in fact non-Jewish revolutionaries who had murdered Pogrebnii, though this did not seem to matter in the chaos that followed. ${ }^{69}$ In a similar example, crowds of URP activists assembled at the Old Christian cemetery in Odessa after the recent death of a police official, Kharchenko, protesting that he had been killed by revolutionaries. However, in this case URP activists promised to bring violence upon all the enemies of Russia, and not only Jews.

The URP presented their funerals as religious and spiritual events that were disrupted by subversive forces. However, though URP activists claimed to support the regime, many police reports displayed concerns about the potential for these events to turn into sites of mass unrest. The question of violence was central to this. Increasingly, the spontaneity of the right was feared by local authorities, in no small part due to the responses that they could elicit from other elements of the community. Police reports noted this and requested the banning of 'political elements from the religious processions', a demarcation that included the far right. ${ }^{70}$ In Odessa, a large city far from the imperial centres of Moscow and St Petersburg, Russia's rulers were keen to contain all possible sources of disruption. One example was when a delegation from the Odessa branch of the URP under the leadership of Count Aleksei Konovnitsyn appeared at the funeral for a member of the URP killed in clashes with revolutionaries in the city in November 1907. The delegation drew revolvers from their pockets and gave a ten-shot salute for the deceased. Unsurprisingly given the violent actions of URP fighting organisations (druzhiny) at universities and workers' meetings in Odessa over the previous several days, undercover police agents at the funeral were concerned by the presence of armed crowds of right-wing activists. ${ }^{71}$ The special section of the police often sent agents to monitor such events. ${ }^{72}$

A particular concern was the emergence of Jewish self-defence groups, which carried out acts of violence in response to the right's activities. ${ }^{73}$ At the funeral held in early September 1907 for a police official, Kharchenko, URP activists converged on the surrounding streets and at a nearby hospital, urging retribution against the 'Jews' who 'murdered' him, and presented Kharchenko as a martyred victim of revolutionary violence. The atmosphere in the neighbourhood following the interment of Kharchenko was so tense that it was feared another pogrom, like the one of October 1905, could break out in Odessa. Faced with this possibility, officials from the police and the army, led by the mayor of the city, V. D. Novitskii, colluded to stop fresh outbreaks of violence by increasing the police presence and arresting wandering bands of URP activists. This crackdown was pursued due to the fear of the violent nature of many of the 'riff-raff' in the URP, and the appearance of Jewish self-defence groups in response to promises of violence to be carried out against Odessa's Jews. On 3 September 1907, one of the Jewish self-defence forces, the Young Will, appeared after a band of URP supporters had assembled outside a Jewish hospital, whereupon several of the followers of the group brandished revolvers and fired shots into nearby crowds of rightist activists. It is unclear how many died in this collision, but it certainly caused a panic, and was reported in many newspapers in the following days. Groups of black-shirted URP activists, themselves armed, fled at the appearance of this wellorganised and destructive group that adopted a fight-fire-with-fire approach and was prepared to meet right-wing destructiveness with its own decisive measures. ${ }^{74}$

The URP was hardly unique amongst rightist organisations in adopting a populist and demagogic style - that trend was almost universal on the right - but was distinct 
in that it came closest to achieving the monarchist aim of mass mobilisation. URP rituals called for the steadfast defence of Russia and its values but, in contrast to the case of the RMP cited above, these funerals and their associated demonstrations had a more militant, demagogic and violent character. The difference in the rituals adopted shows the fractured nature of the monarchist movement. Though it had been tried before under the hand of the government through the Zubatov experiment, monarchist populism was expanding and developing away from the autocracy. The actions of groups such as the URP showed how an alternate vision of monarchism was in development amongst the most extreme factions on the right. ${ }^{75}$ Instances of URP involvement in right-wing terrorism, such as the attempt on the life of Prime Minister Sergei Witte, in addition to the chaotic rightist mob violence that accompanied many of its public activities, show the means that some elements on the right were prepared to adopt to achieve a 'united and indivisible' Russia. ${ }^{76}$ However, the regime was suspicious of such autonomous activity. The governor-general of Odessa, I. N. Tolmachev, took steps to ban the URP and other radical rightists from processions held in Odessa on 22 August 1907, after they had appeared at the funerals of townsfolk murdered in clashes between revolutionaries and right-wing groups from 18 to 20 August. ${ }^{77}$ Incidences of unrest from the past few years, not least the widespread peasant disturbances that had occurred across the empire during the revolution of 1905 , doubtless served to influence such attitudes. ${ }^{78}$

\section{Bessarabia Centenary, 1912: nationalism and identity on the imperial periphery}

A final instance showing the right's independent approach to the creation of both Russian and non-Russian identities was the UAM's involvement in the celebrations marking 100 years since Bessarabia became part of the Russian Empire, held between May and June 1912. Bessarabia was a territory annexed after the war of 1806-12 against Turkey, and incorporated many Orthodox believers into the Russian Empire, a point that would be of fundamental importance in the right's construction of the rituals at the centennial. Like the more famous Poltava and Romanov celebrations, the Bessarabia centennial was designed to demonstrate the greatness of the Russian Empire and the Russian people. ${ }^{79}$ How to organise the celebrations set off fierce arguments between two different groups behind the centennial. Central to this conflict was a conception of Russian identity, integral to the right-wing view of how the commemoration was to be presented. What emerged were two concepts of nationalism, one associated with the council originally behind organising the centennial, and another associated with independent right-wing tendencies in the region.

Arguments over Bessarabia's identity and its place in the Russian Empire show the controversy that the nationality question could engender. The two different groups that emerged had divergent views on whether it was religion or nation that should be the central element in the construction of the rituals surrounding the occasion. A. N. Krupenskii, a marshal of the nobility in Bessarabia province from 1908 to 1912, was the leader of the official council for the organisation of the centenary, which first met on 10 May 1911. His view, like that of others on the council, was that the centenary should celebrate Bessarabia's position within the Russian Empire as part of a 'family 
of peoples' (sem'ia narodov). Krupenskii perceived Bessarabia's role as one of the many members of the imperial family. This was in contrast to the autonomous right-wing version. ${ }^{80}$ This was, most of all, associated with the right-wing delegate to the Third and Fourth State Dumas from Bessarabia and the leader of the UAM, Vladimir Purishkevich, with one of his most notable associates in the region being the monk Serafim (Chichagov), Bishop of Kishinev and a leader of the Bessarabia branch of the URP. ${ }^{81}$ Echoing the official position, right-wingers in Bessarabia supported the 'nationalisation' of Bessarabia, in essence a variation of the regime's Russification policy. However, in contrast to the official organisational council, the radical right, led by the UAM leadership in the region and supported by Serafim's propaganda activities, believed that it was religion, rather than nation, that was the key to the successful promotion of the centenary of Bessarabia's unity with the Russian Empire, particularly due to Bessarabia's demographics. Serafim perceived that Bessarabia was not only separate from Moldova, but had a culture closer to that of the Russian people due to the Orthodox nature of many of its inhabitants (for Serafim, like many rightists, to be a 'truly Russian' citizen meant that one had to believe in the Russian Orthodox religion). ${ }^{82}$

The importance of whether the stress of the ceremonials lay on religion or nation can be seen by the activities of the right in the run-up to the official celebrations. Serafim's activities, which included hosting meetings amongst Bessarabia's population that inspired the need for a spiritual revival, were of no small concern to Krupenskii and several of his associates on the official council. Serafim had been actively spreading a message amongst the population in Kishinev that Russia was undergoing a process of 'spiritual rebirth. ${ }^{83}$ The targets of Serafim's speeches were mainly peasants, whom he considered to be good subjects of the tsar. This concerned the committee, as the potential for spontaneous and popular demonstration was all the greater should Serafim be successful in arousing vitriol in the peasants of Kishinev. Serafim held that the 'truly Orthodox' subjects of Nicholas needed to be united, and to achieve this he believed that the rituals of the centenary should be constructed around a religious framework. Activists from the UAM and the URP lobbied the organisational council to change the potential presentation of the ceremonials in the first half of 1912. Midway through the year, Krupenskii resigned from his position as the chair of the committee, probably due to pressure from the right. After this, the right had more leeway to take a greater role in the planning of the ceremonials. ${ }^{84}$ Unlike other celebrations from around the same time, such as the Poltava bicentennial or the Romanov tercentenary, the right was not merely present at the Bessarabia centennial, but took a direct role in shaping how the ceremonials would be conducted in the region. Purishkevich and Serafim's pressure had told in producing a re-shuffled committee, one more receptive to rightwing ideas.

The ceremonials in Kishinev that followed demonstrated the rightist conviction that religion was the central lodestone around which to construct the identity of Bessarabia, given the presence of Orthodox believers. Orthodoxy was portrayed as the bridge between Bessarabia and the rest of the empire, as it was in Kholm, where rightists placed pressure on the government to take action against the Roman Catholic population on the part of 'truly Russian' men (istinno-Russkie liudi). ${ }^{85}$ Furthermore, religion played a major role in the tsar's own view of the events. An official bulletin on the joining of Bessarabia to the Russian Empire, dated 5 May 1912 and signed by Nicholas II himself, noted 'the memorable event that saw hundreds of thousands of Orthodox Christians of 
the same faith take on total Russian citizenship. ${ }^{86}$ Rightist leaders such as Serafim were confident in the success of the celebrations, especially given that the tsar agreed with their interpretation of events. On 16 May 1912 a right-wing demonstration, a jubilee parade, was held in Kishinev. By eight in the morning, a crowd had gathered outside the cathedral, led by Serafim, though accompanied by many other priests and bishops. After the liturgy prayers were sung to the tsar and to Russia. The procession then took to the town square, where members of the Kishinev branch of the URP, students from the nearby school, peasant choirs and various townsfolk had gathered. A central element in this ceremony was the rightist desire to claim mass support and to function purely as a voice for 'the people', ostensibly in opposition to the intelligentsia. An editorial in Purishkevich's journal Priamoi put' (Straight Path) when reporting on the event noted with some pleasure that 'the intelligentsia and the middle classes (sredniaia publika) were excluded from the service. ${ }^{87}$ One of the key distinctions between the right and the establishment was the use of such populist messages. ${ }^{88}$

Rightist ritual activity continued in Bessarabia once the centenary had passed. In December 1912, Priamoi put' reported on the work of the 'patriotic league' in Bessarabia, a group related to the UAM. After the panikhida, dedicated to 'victims of the years of troubles' (smutnye gody), prayers were offered to the health of the tsar. Like the Gringmut funeral, the panikhida demonstrated the centrality of the revolution of 1905 to the monarchist mindset. In the services held, the present era was referred to as a second 'time of troubles', after the first between the death of Feodor Ivanovich in 1598 and the installation of the Romanov dynasty in 1613. I. V. Malinovskii, the chair of the Kishinev branch of the UAM, welcomed the forthcoming collection of patriotic holidays and dedicated his speech to the victims of the revolution of 1905. The main aim of the UAM at this time was, as earlier in the year, to 'unite the Christian population of Bessarabia.' The focus was on both tsar and people. As in the example of Sergei Aleksandrovich, the idea of 'victimhood' is important. The suffering 'good' people had died at the hands of villainous revolutionaries, much like Sergei himself. ${ }^{89}$ When the imperial family was welcomed by a delegation of right-wing groups in Kishinev in June 1914, love for Russian religion as well as love for the Russian tsar was proclaimed. ${ }^{90}$

However, these visions were much contested and inflamed rival nationalisms, as demonstrated by counterdemonstrations, which occurred throughout 1912. The UAM view that a religious and chauvinistic campaign would unite the Russian elements in Bessarabia also had the effect of bringing out into the open Romanian nationalist groups. The transformation of the town centre in Loov (located in Ismail district, Bessarabia) included the public display of Russian symbols, such as flags and Orthodox crosses, and the illumination of the town square in the colours of the imperial standard at night. On 6 May at two o' clock in the afternoon, cries and shouts were heard from the Romanian section of the town, together with 'the sound of a funeral march.' A large crowd of passers-by had gathered around the wharf area. This included a large group in Romanian national dress, with a full brass band playing the Romanian national anthem. A counterdemonstration by members of the crowd playing the Russian national anthem seems to have raised the temperature of the events, whereupon the police were called. They asked the pro-Romanian demonstrators to leave and they peacefully complied. ${ }^{91}$ Police reports monitoring the mood of the people in Bessarabia made frequent reference throughout May and June 1912 to the upturn in Romanian nationalism and anti-Russian demonstrations. Rather than showing a united pro-Russian front 
amongst the townsfolk as was hoped, the celebrations helped to exacerbate divisions amongst many residents, though there was notably little in the way of actual violence. ${ }^{92}$

The role of the right in the Bessarabia ceremonies, on the face of it a victory for the right in terms of producing an organising council more conducive to right-wing ideas, in fact points towards several of the limitations of rightist rituals. Rightists mainly utilised pre-Petrine forms of worship: Russian Orthodox hymns and ceremonials, banners in Church Slavonic, liturgies and hymns. These rituals in Bessarabia were structured around the Church. Modern, national ideologies of nation-building were largely absent from right-wing discourse. Instead, they stuck to a strictly prescribed high culture: a heroic, puritan, and ascetic set of rituals and symbols that appeared authentic to their own members, but were of limited appeal in a multi-confessional, poly-ethnic empire. In Bessarabia, where citizens whom the UAM and other right-wing groups would have considered 'true Russians' were in the minority, this was especially limiting. Indeed, rival nationalist groups were if anything provoked by the right's activities. The rightist-organised celebrations led to a more divisive set of ceremonials than may have been the case had the regime's original plans been followed. Consequently, the rightist notion of popular observance was shown to be more problematic than their leaders had initially intended.

\section{Conclusion}

The death of a leader of the right, the activities of militant factions in Ukraine and the work of the right in influencing an official demonstration, when considered together, show that the right was not a uniform entity, but one of contrast and ambiguity. But these cases do possess several consistent features. The ancient symbols of religious Orthodoxy were used to situate these ritual activities on a different level from political problems in contemporary Russia, which activists widely perceived to be negative. Themes that play a large role in the Christian tradition featured heavily. A concept of 'shared suffering' involving a rightist leader, then the followers, emerges. Using established themes did not, however, stop the rituals becoming the subject of controversy, from the perspective of both the regime and Jewish self-defence groups in Odessa, and for Romanian nationalists in Bessarabia. The creation of these conflicts was obviously an end that right-wing groups such as the URP and the UAM desired, as can be seen from their fanning of tensions across the empire, but the extent to which this ended up proving counter-productive to their aims in other areas was not fully anticipated. Other national, religious and political groups were frequently at odds with rightwing activists, and whilst rightists themselves may not have represented a subversive presence, the suspicions of the authorities were only sharpened by their tendency to cause controversy. In every example pronounced dissatisfaction with the status quo emerges, demonstrated by a widespread rejection of Russian modernity, including verbal criticism of the State Duma, or even the use of violence in reaction to wider socio-political developments occurring in the Russian Empire. These developments represented the fracturing of groups in support of the autocracy.

Furthermore, rightists were beginning to develop a view of monarchism quite different from that adopted by the regime in previous decades. In Ukraine, a central thematic departure centred on the conception of the narod in the right's scenario. Unlike the 
case with those of the imperial regime, the people had progressed from observers to participants and, finally, to the central subjects in the rituals of the radical right, as the URP attempted to create its own idea of sacred space via public rituals using ideas of the purity of the Russian people. Conceptions of the Russian nation, as opposed to the Russian people, played a lesser role. One of the most notable elements of this was populism - in one respect, the ideology of the right mirrored that of the populist movement of the $1860 \mathrm{~s}$ and $1870 \mathrm{~s}$ in giving 'the people' cult-like status. ${ }^{93}$ Therefore, in addition to the right's self-presentation as protectors of the autocratic tradition, activists demonstrated a more widely held desire to create a mass appeal. When considering why right-wing mass mobilisation did not generate an even wider pull, the conflicts caused by their activities provide one explanation, but another is the lack of originality and pronounced negativity of right-wing symbolism in itself. The right's ideology did not in fact go far enough in providing a genuinely popular alternative to left-wing and liberal movements. The inadequately developed symbolic and political emblems of the far right, many of which were derivative of the regime's own religious and popular ideals, were, in the long run, insufficient for rightist aspirations. The right instead placed much of its energy into creating wholly negative emblems, such as the pursuit of 'enemies of the people' - groups including Jews and bureaucrats. ${ }^{94}$ Unlike certain right-wing tendencies in twentieth-century Europe, the Russian right did not manage to find genuinely popular symbols and rituals that had wide social appeal, and ended up caught between the ideas of elitist gentry organisations and a demagogical, incomplete populist nationalism. These tactical shortcomings had the implication that by the outbreak of war in 1914 the right was much depleted as an independent force. Such failures left in tatters its desire to unite the Russian Empire as an army of many millions and, eventually, would pave the way for revolution.

\section{Acknowledgements}

The author would like to thank the people who provided valuable feedback on earlier drafts of this article: Peter Waldron, Dominic Lieven, Matthew Rendle, Tom T. Trice, Jonathan Waterlow and Andrew Willimott, and two anonymous reviewers of an earlier draft via the Revolutionary Russia website.

\section{Notes}

1. Symbols and rituals used by the regime have come under wider examination in recent years. Examples of this secondary literature include Tsimbaev, 'Fenomen iubileimanii v rossiiskoi obshchestvennoi zhizni kontsa XIX-nachala XX veka', 98-108.

2. Bogatyr' mysli i dela: pamiati Vladimira Andreevicha Gringmuta. Izdanie russkogo monarkhicheskogo sobraniia $v$ Moskve, 21.

3. For more on the origins of the organised right, see Rogger, 'The Formation of the Russian Right: 1900-1906'. In Jewish Policies and Right-Wing Politics in Imperial Russia, 188-211.

4. General surveys of the formation, ideology and activities of the major right-wing groups can be found in Stepanov, Chernaia sotnia v Rossii, 1905-1914; Rawson, 
Russian Rightists and the Revolution of 1905; Iu. I. Kir'ianov, Pravye partii v Rossii, 1911 1917 and most recently Vydra, Život za Cara? Krajní pravice v préedrevolučním Rusku.

5. In the existing literature, social and cultural perspectives on the right have generally been overlooked in favour of examinations of political and institutional themes. Two important pieces that analyse rituals and symbols are Löwe, 'Political Symbols and Rituals of the Russian Radical Right, 1900-1914'; and Vydra, Život za Cara?, 333-56.

6. The outstanding study of monarchist ideology in late imperial Russia is Wortman, Scenarios of Power, Vol. 2. Another useful analysis is Cherniavsky, Tsar and People.

7. These techniques were also used in other monarchist states, such as the German Empire. Mosse, The Nationalization of the Masses, 1-3.

8. Stepanov, Chernaia sotnia, 87.

9. One example of this was the mass demonstrations of the Romanov tercentenary in 1913. Though radical right groups such as the URP were present, the regime downplayed the right's participation, instead drawing attention to crowds of peasants. See Wortman, Scenarios of Power, Vol. 2, 424.

10. Cherniavsky, Tsar and People, 187.

11. Priamoi put', (December 1912): 227.

12. Aksakov, Polnoe sobranie sochinenii, Vol. 5, 21-22. See also Cherniavsky, Tsar and People, 214-15.

13. Moskovskie vedomosti, no. 141 (June 1906): 1. Whether 'Russian' was an ethnic (russkii) or national (rossiiskii) quality was a central subject of discussion in conservative, nationalist and rightist circles in this period. See Loukianov, "'Russia for Russians" or "Russia for Russian Subjects"?', 87.

14. In one issue of Church News from 1909, Vostorgov praised Peter as a hero, warrior and visionary who had an unassailable relationship with the people of Russia. See Tserkovnye vedomosti, no. 8 (February 1909): 53. Vostorgov was chair of the Russian Monarchist Union and a prominent URP activist who gave speeches about the movement across the empire. For background on Vostorgov, see Stepanov and Ivanov, eds. Chernaia sotnia. Istoricheskaia entsiklopediia, 117-23.

15. There are surprisingly few historical (as opposed to sociological) investigations on death, and those that do exist tend to be works of episodic, rather than prolonged, analysis. One exception is Whaley, Mirrors of Mortality: Studies in the Social History of Death. See especially Whaley, 'Introduction', 1-14.

16. Worobec, 'Death Ritual Among Russian and Ukrainian Peasants: Linkages Between the Living and the Dead', 11-33.

17. Some sociological analyses of ritual can be found in Geertz, 'Religion as a Cultural System', in The Interpretation of Cultures, especially 91, 112-13; Bell, Ritual Theory, Ritual Practice. For the relationship between ritual and politics, see Kertzer, 'The Role of Ritual in Political Change', 53-73.

18. Geertz, Religion as a Cultural System, 88.

19. Levitskii, 'Pravye partii', 351.

20. This concept of 'sacred space' has been explored in the context of state funerals in France of the Third Republic. Ben-Amos, 'The Sacred Center of Power'.

21. Reports on the church can be found in the right-wing press, for example Priamoi put' (December 1912): 220-21; Obraztsov, Torzhestvo russkogo ob"edineniia: osviashchenie "narodnogo doma" Ekaterinoslavskogo otdela soiuza russkogo naroda 5-go oktiabria 1910 goda, 1. The reference to the present era as a 'time of troubles' was very common 
in right-wing circles. See for example Moskovskie vedomosti, no. 281 (October 1905): 1. The number of examples could easily be multiplied.

22. On occasion, the regime supported such ventures. One example was the funding given to Nikolai Markov, a right-wing member of the Third and Fourth State Dumas and founder of the newspaper Kurskaia byl' (Kursk's Past) who accepted a subsidy of 12,000 rubles a month from 1909 onwards in support of his paper Zemshchina (Realm), and for distribution to other right-wing organisations. Shchegolev, ed., Padenie tsarskogo rezhima, Vol. 5, 409-13.

23. The creation of cults was not, of course, limited to Gringmut. Another example was the religious celebrations in memory of Father Ioann of Kronstadt. See for example Vestnik Russkogo sobraniia, no. 18 (April 1909): 5.

24. For background on Gringmut, see: Chernaia sotnia. Istoricheskaia entsiklopediia, 15258; Stepanov, 'Bogatyr' mysli i dela, Vladimir Andreevich Gringmut (18511907)', 143-55; Vydra, 'Na stráži samodéržavi'; Rawson, Russian Rightists, 21-33.

25. Stepanov, 'Bogatyr' mysli i dela: pamiati Vladimira Andreevicha Gringmuta', 287-95. Father Ioann Vostorgov repeatedly praised Gringmut in his own public appearances and played a prominent role in the development in the Gringmut cult.

26. Ibid., 287.

27. Gringmut, Vladimir Andreevich Gringmut: ocherk ego zhizni i deiatel'nosti, 119.

28. Stepanov, 'Bogatyr' mysli i dela', 294.

29. Ibid., 290.

30. Vestnik Russkogo sobraniia, no. 11 (March 1909): 8; nos. 22/23 (May 1909): 8-9.

31. Ibid.

32. Rawson, Russian Rightists, 32-33.

33. Griffin, The Nature of Fascism, 42, 197.

34. Gringmut, Ocherk ego zhizni i deiatel'nosti, 78-9.

35. Stepanov, 'Bogatyr' mysli i dela', 207.

36. Moskovskie vedomosti, no. 76 (April 1908): 3.

37. Moskovskie vedomosti, no. 141 (June 1906): 1; Gringmut, Sobranie statei, 1896-1907, Vol. 3, 173-78.

38. Stepanov, 'Bogatyr' mysli i dela', 302-05. See also Grazhdanin, no. 74 (September 1907): 10; no. 88 (November 1907): 15.

39. Gosudarstvennyi arkhiv Rossiiskoi Federatsii (hereafter GARF), f. 102.OO, op. 316, (1905 g.), d. 999, ch. 39, t. 5. l. 167: Russkii vostok, July 29, 1909. On B. V. Nazarevskii, see Chernaia sotnia. Istoricheskaia entsiklopediia, 339-40.

40. Mirnyi trud, no. 10 (1907): 205.

41. Stepanov, 'Bogatyr' mysli i dela', 15.

42. Ibid., 20, 32.

43. Two of these works have been cited here: 'Bogatyr' mysli i dela' and Ocherk ego zhizni i deiatel'nosti. Gringmut's collected essays were published between 1910 and 1913 under the title Gringmut, Sobranie statei, 1896-1907. 4 Vols.

44. Stepanov, 'Bogatyr' mysli i dela', 224. See also a tribute by father Ioann Vostorgov in Mirnyi trud, no. 10 (1907), 185-92.

45. Gringmut, Ocherk ego zhizni i deiatel'nosti, 73.

46. Repnikov, Konservativnye kontseptsii pereustroistva Rossii, 194-96.

47. Ibid., 194.

48. Stepanov, 'Bogatyr' mysli i dela', 153.

49. Vostorgov, Piat' rechei v pamiat' V. A. Gringmuta, 33-34. 
50. Ibid., 33-34. See also Vostorgov, Polnoe sobranie sochinenii, Vol. 3, 347-49, one of five speeches he made in 1907 commemorating the life and work of Gringmut; and Vestnik Russkogo sobraniia, no. 25 (October 1909): 1-2.

51. Istoricheskii vestnik, no. 120 (June 1910): 1105-07. See also Moskovskie vedomosti, no. 93 (April 1910): 1-2; no. 94 (April 1910) 3-4; no. 100 (May 1910): 4; Novoe vremia, no. 12255 (April 1910): 2.

52. Istoricheskii vestnik, no. 120 (June 1910): 1105-07.

53. Grazhdanin, no. 15 (May 1910): 11-12. See also Vostorgov's speech from Gringmut's funeral, re-printed in Vostorgov, Polnoe sobranie sochinenii, Vol. 3, 340-46.

54. Priamoi put' (April 1910): 30-31.

55. Today, no trace of the monument remains in Mogilev, as the Bolsheviks removed the Gringmut memorial after 1917. However, the exact circumstances of its removal are uncertain.

56. Men'shikov, Natsional'naia imperiia, 195; Novoe vremia, no. 11336 (October 1907): 2-3.

57. Herlihy, Odessa: A History 1874-1914, 251.

58. Rawson, Russian Rightists, 242.

59. It is difficult to calculate the overall numerical strength of the right with certainty due to incomplete data and poor record keeping amongst rightist organisations. This estimate has been arrived at from calculating numbers via police reports housed in GARF, F. 102, 4-e d-vo, op. 1907, d. 164. In 1907, the department of police estimated the membership of the URP across the empire at 358,758. Membership of other monarchist groups totalled 47,794. See also Stepanov, Chernaia sotnia, 105, 108-09.

60. The Jewish Labour Bund of Poland, Russia and Lithuania, or Bund for short (18971920) played a prominent role in the propaganda of the URP and other right-wing radicals. Right-wing groups portrayed a scenario where the typical Jew was also a professional revolutionary, partly based on the disproportionate number of Jews in the leadership of revolutionary movements. See Weinberg, 'The Russian Right Responds to 1905', and the relevant chapters in Frankel's Prophecy and Politics.

61. See for example, GARF, f. 102.OO, op. 316, (1905 g.), d. 999, ch. 39, l. A, t. 1, 1. 316: Russkoe znamia, February 19, 1907. The list of examples of similar statements from right-wing organisations could be multiplied hundreds of times.

62. The report from Senator Kuzminskii, sent to Odessa to compile an investigation into the reasons for the pogroms in the city in late 1905, mentioned funeral processions in his report several times: Materialy $k$ istorii russkoi kontr-revolutsii, Vol. 1: pogromy po offitsial'nym dokumentam, CXXXIII-CXXXIV; Kievskii i Odesskii pogromy $v$ otchetakh senatorov Turay i Kuzminskago, 14-16. In the cases cited, URP bands appeared with red banners (representing the blood of Christ) bearing the image of Georgii Pobedonosets at student and revolutionary funerals. This led to counter-violence from militant opponents, and disorders often followed for days before dying out.

63. Gringmut's publication Moskovskie vedomosti first used the nationalist slogan 'Russia for the Russians' in the mid-nineteenth century, one of the first newspapers to do so. This banner has been revived amongst contemporary Russian nationalist groups. Gringmut, Sobranie statei, Vol. 3, 212.

64. One example of this mentality can be found in GARF, f. 102.OO, op. 316, (1905 g.), d. 999, ch. 39, l. A, l. 214 c: Russkaia rech', May 14, 1907.

65. Lambroza, 'The Pogroms of 1903-1906'.

66. Viktorov and Chernovskii, Soiuz russkogo naroda, 395-96. 
67. GARF, f. 102.OO, op. 316, (1905 g.), d. 999, ch. 39, l. A, l. 214 b: Russkaia Rech, May 12, 1907.

68. Viktorov and Chernovskii, Soiuz russkogo naroda, 217-18.

69. Voskhod, no. 9 (May 1906): 21. For overviews of right-wing anti-Semitism and the pogroms, see Löwe, The Tsars and the Jews, 267-72; Klier and Lambroza, eds., Pogroms: Anti-Jewish Violence in Modern Russian History; Weinberg, The Revolution of 1905 in Odessa, 136-41.

70. GARF, f. 102.OO, op. 316, (1905 g.), d. 999, ch. 39, t. 2, ll. 50-50 ob.: Telegramma ot direktora departamenta politsii, January 1907.

71. Some of these disorders from the first half of November 1907 involved a URP combat organisation called the White Guard (Belaia grardiia) operating under the leadership of Baron Bueller, an associate of Konovnitsyn, and its actions at Odessa University, threatening students and disrupting lectures. See for examples a mixture of police reports and newspaper articles in GARF, f. 102.OO, op. 316, (1905 g.), d. 999, ch. 39, 1. A, t. 1, ll. 56, 57, 58, 60, 60 ob., 61, 62 ob.

72. GARF, f. 102.OO, op. 316, (1905 g.), d. 999, ch. 39, l. A, t. 1, 1. 72: Prokuror Odesskoi sudebnoi palaty-A. I. Konovnitsyn.

73. On Jewish self-defence, see Surh, 'Jewish Self-Defense, Revolution, and Pogrom Violence in 1905', 55-74; idem., 'Russia's 1905 Era Pogroms Reexamined'.

74. This incident is discussed in the following newspaper and police reports in GARF, $f$. 102.OO, op. 316, (1905 g.), d. 999, ch. 39, 1. A, t. 3, 1. 17: Birzhevye vedomosti, September 3, 1907; 1. 18, Novoe vremia, September 4, 1907; 1. 19: Birzhevye vedomosti, September 4, 1907; 1. 21: Russkoe slovo, September 4, 1907; l. 22: Russkoe slovo, September 4, 1907; 1. 27: police report from V. D. Novitskii; l. 28: Razbor shifrovannoi telegrammy iz Odessy, V. D. Novitskii-g. direktora departamenta politsii, September 13, 1907.

75. For an analysis of this, see Schneiderman, Sergei Zubatov and Revolutionary Marxism.

76. Lauchlan, 'The Accidental Terrorist'.

77. GARF, f. 102.OO, op. 316, (1905 g.), d. 999, ch. 39, l. A, ll. 346 ob.-347.

78. 'Agrarnoe dvizhenie v 1905 g. po otchetam Dubasova i Panteleeva', Krasnyi arkhiv, 45/11-12 (1925): 182-92.

79. Wortman, Scenarios of Power, Vol. 2, 236-37.

80. Kushko, 'Ritualy imperii i natsii v Bessarabskom kontekste v nachale XX v.', 298.

81. For background on Serafim, see Chernaia sotnia. Istoricheskaia entsiklopediia, 477-80.

82. Kushko, 'Ritualy imperii i natsii', 300-01.

83. Ibid., 304. Like many areas of right-wing activity, Kishinev had a large Jewish population: around 45 per cent of the population of 110,000 based on data from the 1897 census. Evreiskaia entsiklopedia: svod znanii o evreistve i ego culture v proshlom i nastoiashchem, Vol. 9, 504-07; Pervaia vseobshchaia perepis' naseleniia rossiiskoi imperii, 1897 g., Bessarabskaia gubernia. Vol. 3, 74-93.

84. Löwe, Political Symbols and Rituals, 455-56; Kushko, Ritualy imperii i natsii, 301-02.

85. For a detailed analysis of the impact of Russian nationalism in Kholm, see Weeks, Nation and State in Late Imperial Russia, 172-92.

86. GARF, F. 102, 4-e d-vo, op. 121, 1912 g., d. 179, l. 11: Biuro Russkoi pechati, St Petersburg, May 5, 1912. Signed 'Nikolai' (Tsar).

87. Priamoi put' (May 1912): 750. For a typical example of this anti-intelligentsia ideology, see B. V. Nazarevskii, writing in Moskovskie vedomosti, no. 181 (July 1906): 2.

88. Priamoi put' (May 1912): 750.

89. Priamoi put' (December 1912): 220-21. 
90. Vestnik Soiuza russkogo naroda, no. 186 (June 1914): 17.

91. GARF, F. 102, 4-e d-vo, op. 121, 1912 g., d. 179, l. 16: Russkie vedomosti, May 28, 1912.

92. This demonstration is referenced again in police reports in ibid., ll. 2-2 ob., 6-6 ob., 18-18 ob.

93. Cherniavsky, Tsar and People, 194-95.

94. Figes and Kolonitskii, Interpreting the Russian Revolution, 156-58.

\section{References}

Aksakov, I. S. Polnoe sobranie sochinenii, Vol. 5. Moscow: Izdanie knizhnogo magazina N.G. Martynova, 1886.

Bell, C. Ritual Theory, Ritual Practice. Oxford: Oxford University Press, 1992.

Ben-Amos, A. 'Monuments and Memory in French Nationalism'. History and Memory 5, no. 2 (1993): 50-81.

- 'The Sacred Center of Power: Paris and Republican State Funerals'. Journal of Interdisciplinary History 22, no. 1, spring (1991): 27-48.

Berger, P. L. The Sacred Canopy: Elements of a Sociological Theory of Religion. Garden City, NY: Doubleday Anchor Books, 1969.

Bogatyr' mysli i dela: pamiati Vladimira Andreevicha Gringmuta. Izdanie russkogo monarkhicheskogo sobraniia v Moskve. Moscow: Russkaia pechatnia, 1909.

Cherniavsky, M. Tsar and People: Studies in Russian Myths. New Haven and London: Yale University Press, 1961.

Evreiskaia entsiklopediia: svod znanii o evreistve i ego culture v proshlom i nastoiashchem. Vol. 9. St. Petersburg: Obshchestva dlia nauchnykh evreiskikh izdanii i izd-vo BrokgauzEfron, 1911.

Ferenczi, C. 'Freedom of the Press, 1905-1914'. In Civil Rights in Imperial Russia, edited by O. Crisp and L. Edmondson. Oxford: Clarendon Press, 1989, 191-214.

Figes, O. and B. Kolonitskii. Interpreting the Russian Revolution: The Language and Symbols of 1917. New Haven and London: Yale University Press, 1999.

Frankel, J. Prophecy and Politics: Socialism, Nationalism, and the Russian Jews, 1862-1917. Cambridge: Cambridge University Press, 1981.

Geertz, C. The Interpretation of Cultures: Selected Essays. London: Fontana Press, 1973.

Griffin, R. The Nature of Fascism. New York: St Martin's Press, 1991.

Gringmut, V. A. Sobranie statei, 1896-1907, 4 Vols. Moscow: Univ. tip, 1908-10.

Herlihy, P. Odessa: A History 1874-1914. Cambridge, MA: Harvard Ukrainian Research Institute, 1986.

Kertzer, D. I. 'The Role of Ritual in Political Change'. In Political Anthropology, Vol. 2: Culture and Political change, edited by M. J. Aronoff. New Brunswick, NJ: Transaction Books, 1983, 53-73.

Kievskii i Odesskii pogromy v otchetakh senatorov Turay i Kuzminskogo. St Petersburg: Letopisets, 1907.

Kir’ianov, Iu. I. Pravye partii v Rossii: 1911-1917. Moscow: Rosspen, 2001.

Kizenko, N. 'The Savior on the Waters Church War Memorial in St. Petersburg'. In Picturing Russia: Explorations in Visual Culture, edited by V. Kivelson and J. Neuberger. New Haven and London: Yale University Press, 2008, 124-27.

Klier, J., and S. Lambroza. Pogroms: Anti-Jewish Violence in Modern Russian History. Cambridge: Cambridge University Press, 1992. 
Krasnyi arkhiv, $1925-30$.

Kushko, A. 'Ritualy imperii i natsii v Bessarabskom kontekste v nachale XX v'. In Bessarabiia v sostave Rossiiskoi imperii 1812-1917, compiled by A. Kushko and V. Taki. Moscow: Novoe literaturnoe obozrenie, 2012, 293-321.

Lambroza, S. A. 'The Pogroms of 1903-1906'. In Pogroms: Anti-Jewish Violence in Modern Russian History, edited by J. Klier and S. Lambroza. Cambridge: Cambridge University Press, 1992, $195-247$.

Lauchlan, I. 'The Accidental Terrorist: Okhrana Connections to the Extreme-Right and the Attempt to Assassinate Sergei Witte in 1907'. Revolutionary Russia 14, no. 2, December (2001): $1-32$.

Levitskii, V. 'Pravye partii'. In Obshchestvennoe dvizhenie v Rossii v nachale XX-go veka, Vol. 3. Part 5, edited by L. Martov, P. Maslov and A. Potresov, St Petersburg: Tipografiia t-va 'obshchestvennaia pol'za', 1914, 347-469.

Lindemann, A. S. The Jew Accused: Three Anti-Semitic Affairs (Dreyfus, Beilis, Frank), 18941915. Cambridge: Cambridge University Press, 1991.

Loukianov, M. N. “"Russian for Russians” or "Russia for Russian Subjects”? Conservatives and the Nationality Question on the Eve of World War One'. Russian Studies in History 46, no. 4, spring (2008): 77-92.

Löwe, H.-D. 'Political Symbols and Rituals of the Russian Radical Right, 1900-1914'. Slavonic and East European Review 76, no. 3, July (1998), 443-66.

. The Tsars and the Jews: Reform, Reaction and Anti-Semitism in Imperial Russia, 1772 1917. Oxford: Oxford University Press, 1992.

Luk'ianov, M. N. 'V ozhidanii katastrofy: eskhatologicheskie motivy v russkom konservatizme nakanune pervoi mirovoi voiny'. Russian History 31, no. 4, winter (2004): $419-46$.

Materialy k istorii Russkoi kontr-revolutsii, Vol. 1: pogromy po offitsial'nym dokumentam. St Petersburg: Obshchestvennaia pol'za, 1908.

Men'shikov, M. Natsional'naia imperiia. Moscow: Imperskaia traditsiia, 2004.

Mosse, G. L. The Nationalization of the Masses: Political Symbolism and Mass Movements in Germany From the Napoleonic Wars Through the Third Reich. New York: Meridian, 1975.

Obraztsov, V. A. Torzhestvo russkogo ob"edineniia: osviashchenie "narodnogo doma" Ekaterinoslavskogo otdela soiuza russkogo naroda 5-go oktiabria 1910 goda. Khar'kov: Mirnyi trud, 1910.

Pervaia vseobshchaia perepis' naseleniia rossiiskoi imperii, 1897 g., Bessarabskaia gubernia. Vol. 3. St. Petersburg: Izd. Tsentral'nogo statisticheskogo komiteta Ministerstva vnutrennikh del, 1905.

Rawson, D. Russian Rightists and the Revolution of 1905. Cambridge: Cambridge University Press, 1995.

Repnikov, A. V. Konservativnye kontseptsii pereustroistva Rossii. Moscow: Academia, 2007.

Rogger, H. Jewish Policies and Right-Wing Politics in Imperial Russia. Berkeley and Los Angeles: University of California Press, 1986.

- 'Was there a Russian Fascism? The Union of the Russian People'. Journal of Modern History 36, December (1964): 398-415.

Schneiderman, J. Sergei Zubatov and Revolutionary Marxism: The Struggle for the Working Class in Tsarist Russia. Ithaca and London: Cornell University Press, 1976.

Shchegolev, P. E., ed. Padenie tsarskogo rezhima. Moscow and Leningrad: Gosudarstvennoe izdatel'stvo, 1926.

Shelokhaev, V. V., ed. Russkii konservatizm serediny XVIII-nachala XX veka: entsiklopediia. Moscow: Rosspen, 2010. 
Sidorov, A. L., G. M. Derenkovskii, G. D. Kostomarov, G. N. Kuziukov, and A. M. Pankratova (eds.), Revoliutsiia 1905-1907 gg. v Rossii: dokumenty i materialy, Vol. 1, Part 3. Moscow: Izdatel'stvo akademii nauk, 1955.

Stepanov, A. 'Bogatyr' mysli i dela, Vladimir Andreevich Gringmut (1851-1907)'. In Voinstvo Sviatogo Georgiia: zhizneopisaniia Russkikh monarkhistov nachala XX veka, edited by A. A. Ivanov and A. D. Stepanov. St Petersburg: Tsarskoe selo, 2006, $143-55$.

Stepanov, S. A. Chernaia sotnia v Rossii, 1905-1914 gg. Moscow: Rozvuznauka. 1992.

Stepanov, A. D. and A. A. Ivanov, eds. Chernaia sotnia. Istoricheskaia entsiklopediia 19001917. Moscow: Institut russkoi tsivilizatsii, 2008.

Trice, T. 'Rites of Protest: Populist Funerals in Imperial St Petersburg, 1876-1878'. Slavic Review 60, no. 1, March (2001): 50-74.

Surh, G. 'Jewish Self-Defense, Revolution, and Pogrom Violence in 1905'. In The Russian Revolution of 1905 in Transcultural Perspective: Identities, Peripheries, and the Flow of Ideas, edited by F. Fischer von Weikersthal et al. Bloomington, IN: Slavica, 2013, $55-74$.

. 'Russia's 1905 Era Pogroms Reexamined'. Canadian-American Slavic Studies 44 (2010): 253-95.

Tsimbaev, K. 'Fenomen iubileimanii v Rossiiskoi obshchestvennoi zhizni kontsa XIX- nachala XX veka'. Voprosy istorii, no. 11 (2005): 98-108.

Viktorov, V. P., ed., and A. Chernovskii, comp. Soiuz russkogo naroda. Po materialam chrezvychainoi sledstvennoi komissii vremennogo pravitel'stva 1917g. Moscow and Leningrad: Gosudarstvennoe izdatel'stvo, 1929.

Gringmut, V. A. Vladimir Andreevich Gringmut: ocherk ego zhizni i deiatel'nosti. Moscow: A. A. Levenson, 1913.

Vostorgov, I. Piat' rechei v pamiat' V. A. Gringmut. Moscow: Russkaia pechatnia, 1907.

. Polnoe sobranie sochinenii. 3 vols. Moscow: Russkaia pechatnia, 1914-15.

Vydra, Z. 'Na stráži samodéržaví. Vladimir Andrejevič Gringmut a Ruská monarchistická strana, 1905-1907'. Theatrum historiae, no. 5 (2009): 113-42.

Život za Cara? Krajní pravice v predrevolučním Rusku. Prague: Pavel Mervart, 2011.

Waldron, P. Between Two Revolutions: Stolypin and the Politics of Renewal. DeKalb: Northern Illinois University Press, 1998.

Weeks, T. Nation and State in Late Imperial Russia: Nationalism and Russification on the Western Frontier, 1863-1914. DeKalb: Northern Illinois University Press, 1996.

Weinberg, R. The Revolution of 1905 in Odessa: Blood on the Steppes. Bloomington: Indiana University Press, 1993.

- 'The Russian Right Responds to 1905: Visual Depictions of Jews in Postrevolutionary Russia'. In The Revolution of 1905 and Russia's Jews, edited by S. Hoffman and E. Mendelsohn. Philadelphia: University of Philadelphia Press, 2008, 55-69.

Whaley, J. 'Introduction'. In Mirrors of Mortality: Studies in the Social History of Death, edited by J. Whaley. London: Europa Publications, 1981.

Worobec, C. D. 'Death Ritual Among Russian and Ukrainian Peasants: Linkages Between the Living and the Dead'. In Cultures in Flux: Lower Class Values, Practices, and Resistance in Late Imperial Russia, edited by S. P. Frank and M. D. Steinberg. Princeton, NJ: Princeton University Press, 1994, 11-33.

Wortman, R. Scenarios of Power: Myth and Ceremony in the Russian Monarchy, from Alexander II to the Abdication of Nicholas II. Vol. 2. Princeton, NJ: Princeton University Press, 2000. 